\title{
Effects of Vibration Stress on the Quality of Packaged Apples during Simulated Transport
}

\author{
Hyun Mo Jung ${ }^{1}$, Jeong Gil Park ${ }^{2}$ \\ ${ }^{1}$ Dept. of Visual Design, Kyongbuk Science University, Chilgok, Korea, ${ }^{2}$ Dept. of Biosystems Machinery Engineering, \\ Chungnam National University, Daejeon, Korea
}

Received: January $12^{\text {th }}, 2012$; Revised: February $15^{\text {th }}, 2012$; Accepted: February $24^{\text {th }}, 2012$

\section{Abstract}

Purpose: The characteristics of in-transit vibration stress and possible damage to packaged apples were examined. Methods: A simulated transportation environment with a specific power density profile was used for vibration impact experiments to determine the resulting decrease in packaged apple quality. Apples with or without vibration stress were stored at low temperature $\left(5 \pm 0.8^{\circ} \mathrm{C}, 75-85 \%\right.$ relative humidity) for 30 days. Statistically significant differences ( $\left.\leq 0.05\right)$ were found between apples with and without vibration stress for concentration of oxygen $\left(\mathrm{O}_{2} ; 11.2 \%\right.$ and $14.1 \%$, respectively; initially $20.9 \pm 0.4 \%$ ), carbon dioxide $\left(\mathrm{CO}_{2} ; 26.4 \%\right.$ and $21.8 \%$; initially $\left.1 \pm 0.2 \%\right)$, and ethylene $\left(79.4 \mu \mathrm{LL}^{-1}\right.$ and $55.6 \mu \mathrm{LL}^{-1}$; initially $14.1 \pm 0.6 \mu \mathrm{LL}^{-1}$ ) in the headspace of a gas-collecting container after 30 days of storage. Results: Significant differences were also measured for apples with and without vibration stress with respect to soluble solid content (15.4\% and $14.9 \%$, respectively; initially $12.9 \pm 0.8 \%$ and $13.1 \pm 1.1 \%)$, weight loss ( $10.1 \%$ and $8.2 \%)$, and firmness (139.7 $\mathrm{kPa}$ and $163.3 \mathrm{kPa}$; initially $213.8 \pm 6.2 \mathrm{kPa}$ and $209.1 \pm 7.9 \mathrm{kPa}$ ) after 30 days of storage. Conclusions: The vibration stress clearly accelerated the degradation of apple quality during storage, resulting in increased weight loss, soluble solid content, and headspace $\mathrm{CO}_{2}$ and ethylene production, and decreased firmness and headspace $\mathrm{O}_{2}$.

Keywords: Apple, Quality change, Transportation, Vibration stress

\section{Introduction}

The distribution of agricultural products in Korea has changed substantially in recent years. The purchasing patterns of consumers have become more diverse and skewed towards upscale products, as exemplified by the increased demand for high-quality and safe agricultural products. As such, logistical handling of agricultural products during distribution must take into consideration large volumes, prices, and changing product characteristics.

Because agricultural products can be easily damaged, they require special packaging. Fruit quality declines during storage after harvesting, and to reach consumers fruit products must go through numerous steps including

\footnotetext{
*Comesponding author: Hyun Mo Jung

Tel: +82-54-979-9558; Fax: +82-54-972-9558

E-mail: hmjung@kbsu.ac.kr
}

sorting, packaging, and processing. Fruit damage can occur from mold and bacteria, rats, and other pests, inappropriate temperature and humidity, poor handling, and chemical processes within fruit. Particularly after harvesting, the physiological post-ripening process leads to fruit softening, diminishing storage life.

Fruit and vegetable quality can decline during transport owing to physical and biological damage caused by vibration. The power spectral density (PSD) has frequently been used to measure and analyze transport-induced vibration (Hinsch et al., 1993; Jarimopas et al., 2005; Singh et al., 2007; Rissi et al., 2008). Based on PSD measurements taken during transport of loquat from Spain to Italy, simulated transport vibration using an electro-dynamic shaker showed that most loquats suffered a decline in quality owing to vibration pressure and frictional stress (Barchi et al., 2002). Damage to produce 
owing to transport vibration has also been demonstrated for tomatoes (Olorunda and Tung, 1985; Singh and singh, 1992), potatoes (Grant et al., 1986; Turczyn et al., 1986), peaches (Vergano et al., 1991; Choi et al., 2010), apples (Schulte et al., 1990; Singh and Xu, 1993; VURSAVUŞ and ÖZGÜVEN, 2004), and pears (Slaughter et al., 1993; Berardinelli et al., 2005; Kim et al., 2010).

Ethylene can be produced during storage and transport, and its presence can accelerate ripening and septicity, thereby degrading fruit quality (Stow et al., 2000; Fisk et al., 2008). Ethylene production has been studied in apples under controlled-atmosphere storage (Jung and Choi, 1999), apples treated with hot water (Seo et al., 2005), apples and peaches treated with 1-methylcyclopropene (Choi, 2005), and grapes stored in the cold under various relative humidity conditions (Hong and Lee, 2007). To counter the effects of ethylene, storage under low $\mathrm{O}_{2}$ levels with moderate to high $\mathrm{CO}_{2}$ levels usually extends the shelf life of fresh-cut commodities, although optimal storage conditions depend on the metabolic characteristics of each product (Kader et al., 1989).

In Korea, most harvested apples are transported and distributed by truck, which influences apple quality and marketability. Apple quality is substantially affected by vibration stress caused by the transportation environment. To more fully understand this issue, we measured the effects of vibration stress on the internal quality of packaged apples subjected to simulated transport with a vibration tester in the lab.

\section{Materials and Methods}

\section{Fruit and corrugated fiberboard box materials}

Apples of the 'Fuji' cultivar (harvested in October 2010 in Daegu, Korea) were sorted and packaged in the local packaging center and then stored at $5 \pm 1^{\circ} \mathrm{C}$ with $85 \pm 5 \%$ relative humidity for 2 days prior to the experiment. Selected apples were similar in weight $(0.34 \pm 0.015 \mathrm{~kg})$ and number in a cluster and were free of blemishes and other defects. All samples were washed with $200 \mu \mathrm{LL}^{-1}$ sodium hypochlorite solution at $\mathrm{pH} 8$ to maximize sanitation and then drained for 2 min prior to simulation tests.

The corrugated fiberboard boxes were a modification of the folder-type box (Code No. 0435) regulated by KS T

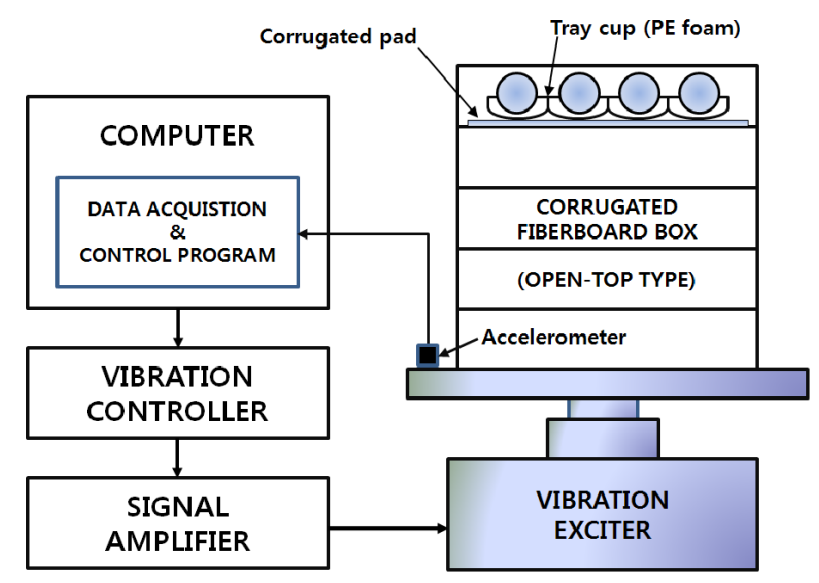

Figure 1. Schematic diagram of the random vibration test apparatus for packaged apples.

1006, which had an open-top configuration. The boxes were made of double-wall corrugated fiberboards with single-ridge B and E flutes in the arched layered fluting medium on the corrugated roll, typically used for smallunit packaging of fruits in Korea. The corrugating medium was reinforced by a lamination of two $\mathrm{S}^{120} \mathrm{kraft}$ papers with $120 \mathrm{~g} / \mathrm{m}^{2}$ basis weight and $9.0 \mathrm{~kg}_{\mathrm{f}}$ ring crush. The exterior of the outside liner board was coated for waterproofing. The box cushioning materials were tray cups of polyethylene foam and a corrugated pad as shown in figure 1. Fuji apples in 5-kg packages were used and there were 12 apples in each box in the experiment.

\section{Random-vibration tests}

A vibration tester (EDS 150, $150 \mathrm{~kg}$, EDS, Austin, TX, USA) was used to generate vibration of packaged apples. The vibration test system consisted of a controllable electronic shaker, an amplifier for the signal from the control device, and an accelerometer controlling the shaker and measuring vibration characteristics (Figure 1). Before the vibration experiment, the apples were stored at $19 \pm 1{ }^{\circ} \mathrm{C}$ and $73 \pm 5 \%$ relative humidity for 1 day in a temperature/humidity-controlled room to adapt the apples to the experimental condition. They were then divided into one group with imposed vibration stress and the control group that was not subjected to vibration. For the vibration test, the apple boxes were stacked in five rows on top of a vibrating table and fixed by applying transparent tape to prevent moving of the sample boxes in a simulated transportation environment.

The vibration experiments entailed random vibration according to the PSD profile regulated by ASTM D3580-95, 


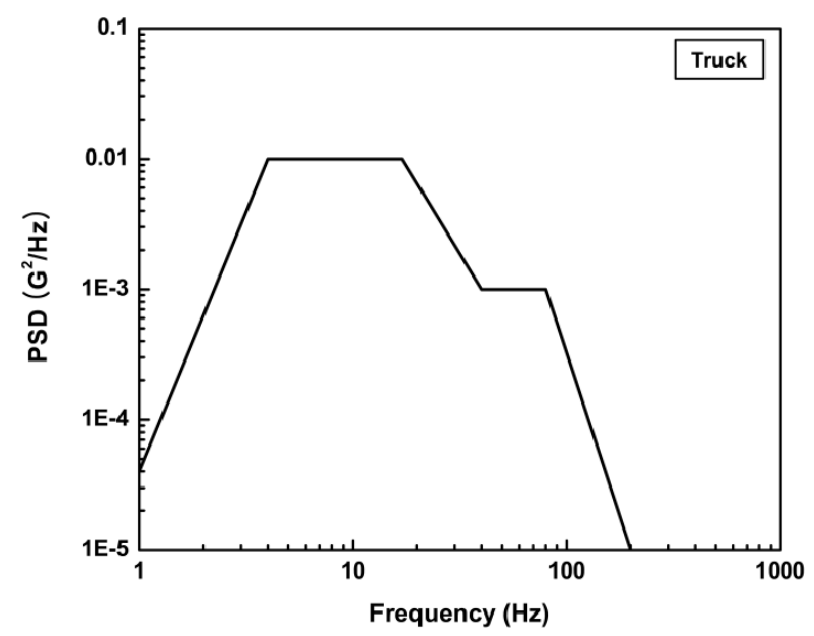

Figure 2. Sample commercial transport vibration test profile by ASTM D4728.

as shown in Figure 2. Random vibration was set so that the initial input value could incrementally increase starting from at least $6 \mathrm{~dB}$ lower than the maximum level. The vibration experiments were continued for $331 \mathrm{~min}$, in accordance with the transportation time from Daegu to the Garak Market in Seoul. Daegu has the largest apple production regions in Korea, and Garak Market is Korea's largest wholesale market of agricultural and marine products. The random-vibration experiment used 1 200 $\mathrm{Hz}$ frequency, with three replications performed to determine the effect of vibration stress on the quality of packaged apples. All experiments were repeated three times with different samples.

\section{Headspace gas analysis}

After the vibration experiment, three apples (1025 \pm $30 \mathrm{~g}$ ) were placed in each gas collection container filled with air $\left(20.9 \% \mathrm{O}_{2}, 1 \% \mathrm{CO}_{2}\right)$, and $\mathrm{O}_{2}$ and $\mathrm{CO}_{2}$ concentrations were determined using an $\mathrm{O}_{2} / \mathrm{CO}_{2}$ analyzer (MultiRAE IR, RAE systems Co., San Jose, CA, USA). A needle was plunged into the gas collection container, and a pump was electronically timed to withdraw the required samples for analysis. Three replications were done to determine $\mathrm{O}_{2}$ and $\mathrm{CO}_{2}$ concentrations inside the containers. Three collections (using a 1-ml syringe) were taken from each container to measure ethylene utilizing a gas chromatograph (GC-14A, Shimadzu, Kyoto, Japan) equipped with an activated alumina column and a flame ionization detector. Three gas collecting containers were randomly selected for gas analysis every 6 days during the 30-day storage period. Three replications were used to determine ethylene concentrations. And these experiments were also done for the control group.

\section{Quality evaluations}

Soluble solids content (SSC) was measured every 6 days using a portable hand-held digital refractometer (PAL-16S, ATAGO Co., Kobe, Japan). Weight loss was measured every 6 days by weighing whole apples. Triplicate measurements were expressed as a percentage loss of the weight taken at the beginning of the experiment. To measure changes in apple firmness, a $5 \mathrm{~mm} \mathrm{~min}^{-1}$ loading rate was applied to apples and a compression test performed with a cylindrical compression jig (10 mm diameter in accordance with ASABE S368.3 (ASABE, 2008)) using a universal compression machine (SY-005, Sunyoung Systec Co., Daejeon, Korea). Fruit firmness is closely related to storability. The compression tests were performed on two opposite surfaces for each sample (Jung et al., 2010). Bioyield strength measured the change in firmness quality every 6 days. Three replications were used to evaluate the quality during the 30-day storage period. These experiments were also done for the control group.

\section{Statistical analysis}

A completely random design was used with the two apple groups, and experimental data were analyzed using SPSS for Windows, Release 9.0.0 (SPSS Inc., Chicago, IL, USA). Analysis of variance was performed to compare changes in quality between the two groups. Duncan's test was used to compare means and establish the significance of differences at the $5 \%$ significance level.

\section{Results and Discussion}

\section{Headspace gases}

Headspace $\mathrm{O}_{2}$ content significantly $(\mathrm{p} \leq 0.05)$ decreased over time up to day 30 in the control group $\left(0.23 \%\right.$ day $^{-1}$, up to $14.1 \%)$ and vibration stress group $\left(0.33 \%\right.$ day $^{-1}$, up to $11.2 \%)$ compared to the initial value $(20.9 \pm 0.4 \%)$, without reaching an equilibrium concentration during storage (Figure 3). Low $\mathrm{O}_{2}$ and high $\mathrm{CO}_{2}$ concentrations slow down respiration and retard ethylene production and thus ripening (Kader and Ben-Yehoshua, 2000). Low $\mathrm{O}_{2}$ promotes anaerobic metabolites (Wszelaki and Mitcham, 2000). Slow changes in headspace $\mathrm{O}_{2}$ composition may be caused by the low respiration rate of apples at low 


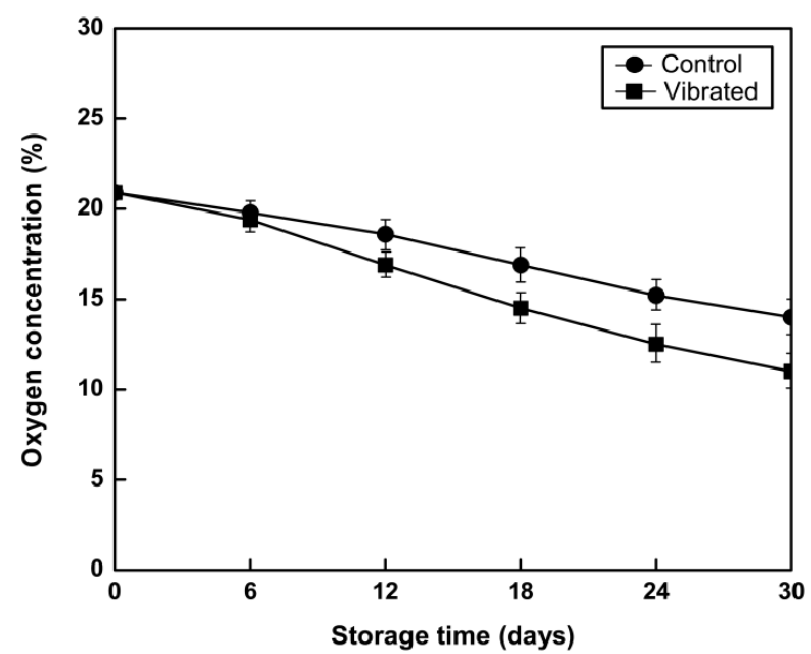

Figure 3. Evolution of the headspace oxygen $\left(\mathrm{O}_{2}\right)$ concentration in two group apples stored at $5^{\circ} \mathrm{C}$ : Control apples not received vibration stress and vibrated apples received vibration stress under transportation environment. The values are mean of five determinations \pm standard deviation.

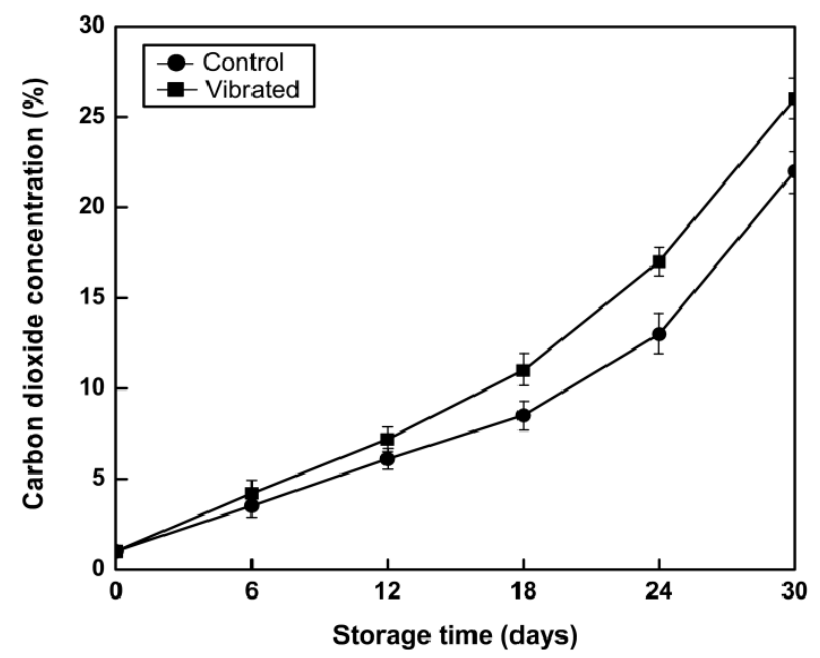

Figure 4. Evolution of the headspace carbon dioxide $\left(\mathrm{CO}_{2}\right)$ concentration in two group apples stored at $5^{\circ} \mathrm{C}$ : Control apples not received vibration stress and vibrated apples received vibration stress under transportation environment. The values are mean of five determinations \pm standard deviation.

storage temperature $\left(5^{\circ} \mathrm{C}\right)$.

In contrast, the $\mathrm{CO}_{2}$ level significantly increased during storage $(\mathrm{p} \leq 0.05)$ in the control group $\left(0.71 \%\right.$ day $^{-1}$, up to $21.8 \%)$ and vibration stress group $\left(0.83 \% \mathrm{day}^{-1}\right.$, up to $26.4 \%)$ compared to the initial value $(1 \pm 0.2 \%)$ (Figure 4). These results suggest that two gases may be inversely correlated during storage.

Ethylene concentrations inside the gas collecting container increased significantly ( $\mathrm{p} \leq 0.05)$ after 12 days storage,

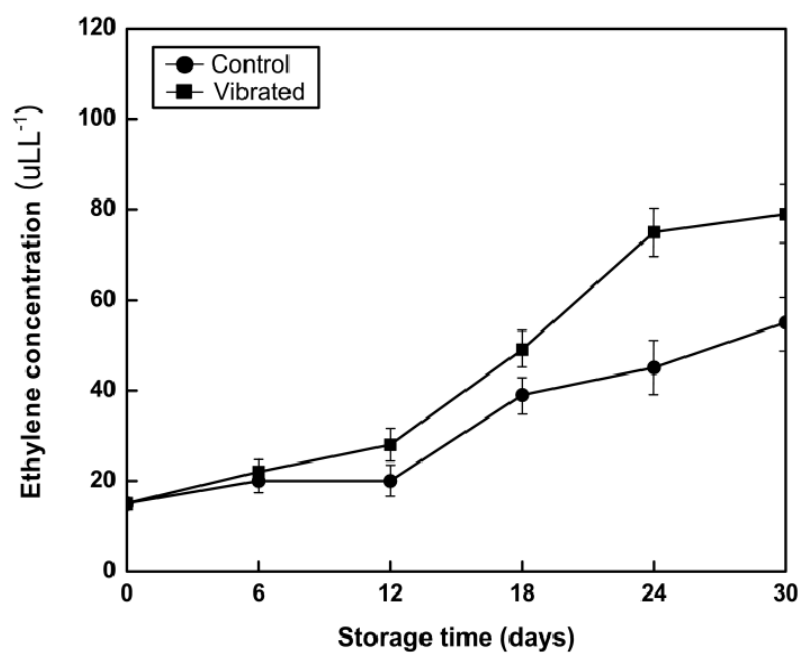

Figure 5. Evolution of the headspace ethylene concentration in two group apples stored at $5^{\circ} \mathrm{C}$ : Control apples not received vibration stress and vibrated apples received vibration stress under transportation environment. The values are mean of five determinations \pm standard deviation.

particularly for apples with vibration stress; whereas less ethylene was produced in control apples during storage (Figure 5). Ethylene concentrations were significantly different ( $\mathrm{p} \leq 0.05)$ between the control group (1.38 $\mu \mathrm{LL}^{-1}$ day ${ }^{-1}$, up to $55.6 \mu \mathrm{LL}^{-1}$ ) and vibration stress group $\left(2.18 \mu \mathrm{LL}^{-1}\right.$ day $^{-1}$, up to $79.4 \mu \mathrm{LL}^{-1}$ ) without reaching an equilibrium concentration throughout storage. Hence, ethylene production increased and accumulated inside the gas collection container throughout storage, but it did not exceed $80 \mu \mathrm{LL}^{-1}$ during storage. Hence, ethylene production increased owing to continued ripening after harvest. Ethylene accelerates fruit ripening, and these results showed that vibration stress during transportation clearly accelerated the degradation of apple quality.

\section{Changes in quality parameters}

\section{Soluble solids content (SSC)}

SSC of apples with or without vibration stress increased $2.5 \%$ and $1.8 \%$, respectively, by 30 days, increasing significantly with storage time in all samples (Figure 6). SSC increases during storage owing to amylase-mediated conversion of starch to sugar (Arpaia et al., 1985). SSC increased more rapidly in apples with vibration stress compared to control apples, suggesting a more rapid ripening of stressed apples under these conditions. Generally, High temperature causes a rapid change in SSC, presumably because of higher enzyme activity and a more rapid conversion of starch to sugar. A slow SSC change indicates 


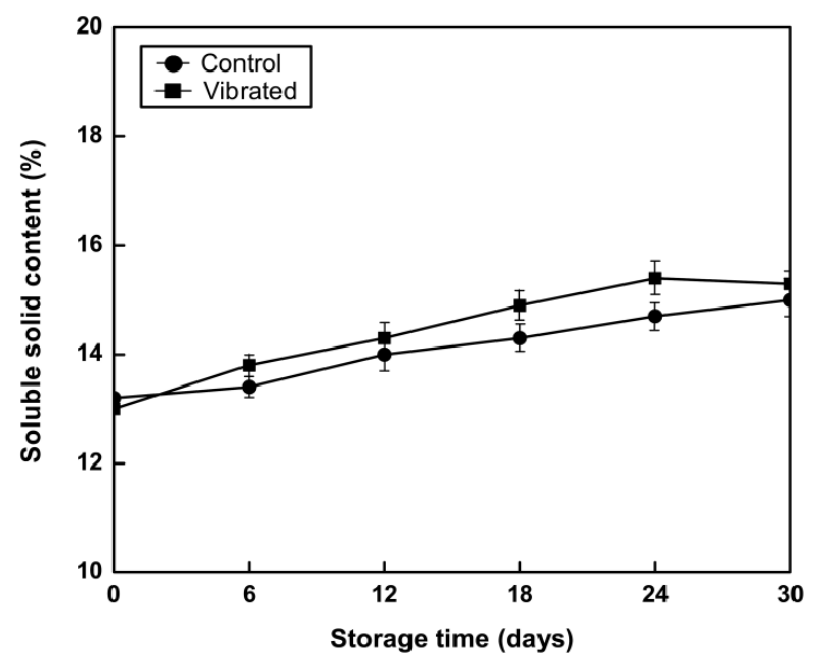

Figure 6. Soluble solids content (\%) in two group apples stored at $5^{\circ} \mathrm{C}$ : Control apples not received vibration stress and vibrated apples received vibration stress under transportation environment. The values are mean of five determinations \pm standard deviation.

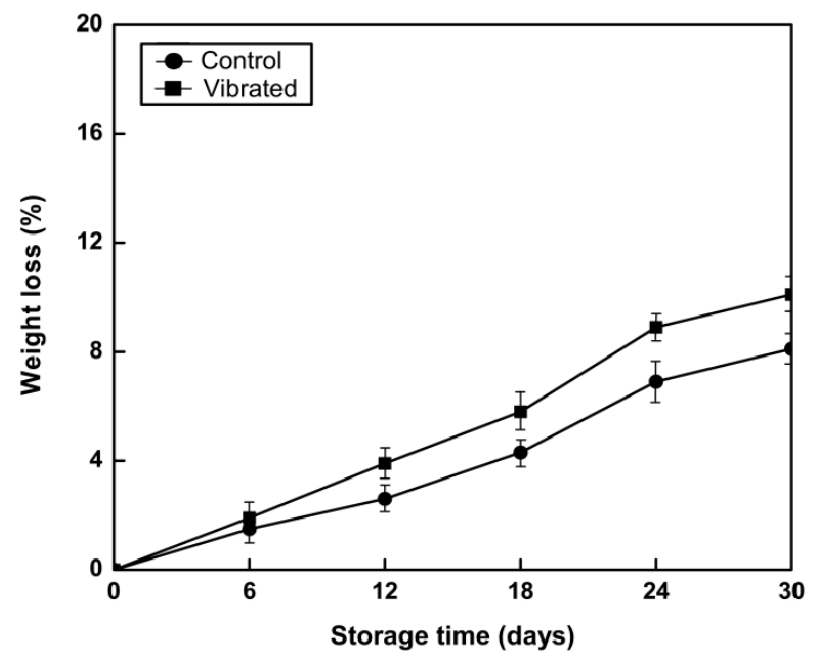

Figure 7. Weight loss (\%) in two group apples stored at $5^{\circ} \mathrm{C}$ : Control apples not received vibration stress and vibrated apples received vibration stress under transportation environment. The values are mean of five determinations \pm standard deviation.

an extension of shelf life (Fuchs et al., 1980).

\section{Weight loss}

Generally, weight loss during storage was expected owing to fruit transpiration. Low-temperature storage at $5^{\circ} \mathrm{C}$ reduced weight loss of apples compared to room temperature storage. Weight loss during the 30 days differed significantly $(\mathrm{p} \leq 0.05)$ between the vibration stress (10.1\%) and control (8.2\%) groups (Figure 7). These results suggest that apples stressed by external vibration may have higher respiration and therefore may

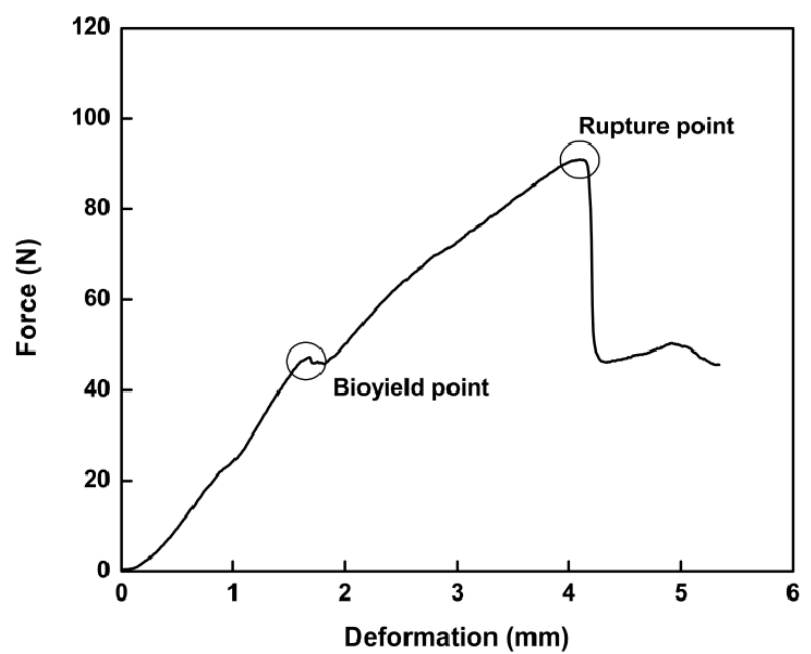

Figure 8. Force-deformation curve of an apple by compression test. Bioyield strength is bioyield point divided by contact area between apple and compression jig.

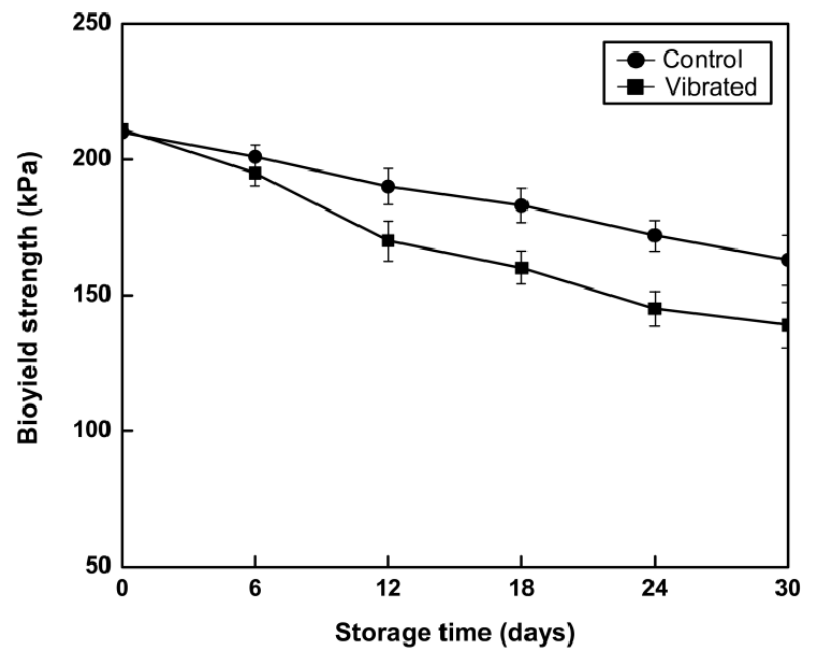

Figure 9. Bioyield strength $(\mathrm{kPa})$ of firmness factor in two group apples stored at $5^{\circ} \mathrm{C}$ : Control apples not received vibration stress and vibrated apples received vibration stress under transportation environment. The values are mean of five determinations \pm standard deviation.

experience more weight loss during storage.

\section{Firmness}

Figure 8 shows the force-deformation curve of apples measured by compression tests, with the bioyield strength indicating a firmness factor. As expected, the firmness of apples in the two groups decreased significantly ( $\mathrm{p} \leq$ 0.05 ) during storage, with $33.2 \%$ (vibration stress) or $21.9 \%$ (control) firmness loss after 30 days (Figure 9). In general, the soft texture of fruit and vegetables is a consequence of many factors such as the loss in cell 
turgor pressure and vascular air and the degradation of cell wall constituents and polysaccharides (Lakshminarayana, 1980). Texture degradation has been closely correlated to ripening. During ripening, there is rapid enzyme synthesis and subsequent SSC release, which would explain the greater softening in ripe fruit. Firmness varies for different ripening conditions in fresh-cut pears (Soliva-Fortuny et al. 2002). There were no significant differences between the two apple groups in fruit firmness after the initial 6 days of storage, but there were significant differences ( $p$ $\leq 0.05$ ) after 6 days. These results indicate that no vibration stress could significantly delay ripening, reduce weight loss, and retain firmness of fresh apples during storage and transport, thus effectively extending shelf life.

\section{Conclusions}

In this study, the effect of vibration stress on the quality of packaged apples was examined using the PSD regulated ASTM D4728 to simulate a laboratory transportation environment. Significant differences were also measured for apples with and without vibration stress with respect to soluble solid content $15.4 \%$ and $14.9 \%$, respectively; initially $12.9 \pm 0.8 \%$ and $13.1 \pm 1.1 \%$ ), weight loss $(10.1 \%$ and $8.2 \%$ ), and firmness (139.7 $\mathrm{kPa}$ and $163.3 \mathrm{kPa}$; initially $213.8 \pm 6.2 \mathrm{kPa}$ and $209.1 \pm 7.9 \mathrm{kPa}$ ) after 30 days of storage. Vibration stress during transportation clearly accelerated the degradation of apple quality, resulting in increased weight loss, SSC, headspace $\mathrm{CO}_{2}$, and ethylene production, and decreased firmness and headspace $\mathrm{O}_{2}$. Further studies are needed to develop proper packaging methods to minimize the degradation of fruit quality by vibration stress during transport.

\section{Conflict of Interest}

No potential conflict of interest relevant to this article was reported.

\section{References}

AArpaia, M. L., F. G. Mitchell, A. A. Kader and G. Mayer. 1985. Effects of $2 \% \mathrm{O}_{2}$ and varying concentrations of
$\mathrm{CO}_{2}$ with or without $\mathrm{C}_{2} \mathrm{H}_{4}$ on the storage performance of kiwifruit. Journal of the American Society for Horticulture Science 110(2):200-203.

ASABE Standards. 2008. S368.3: Compression Test of Food Materials of Convex Shape. St. Joseph, MI: ASABE. ASTM. 2004. D3580-95: Standard Test Methods for Vibration (Vertical Linear Motion) Test of Products. West Conshohocken, PA:ASTM.

Barchi, G. L., A. Berardinelli, A. Guarnieri, L. Ragni and C. Totaro-Fila. 2002. Damage to loquats by vibration simulating intra-state transport. Biosystems Engineering 82(3):305-312.

Berardinelli, A., V. Donati, A. Giunchi, A. Guarnieri and L. Ragni. 2005. Damage to pears caused by simulated transport. Journal of Food Engineering 66(2):219-226.

Chung, H. S. and J. U. Choi. 1999. Production of Ethylene and Carbon Dioxide in Apples during CA Storage. Korean Journal of Postharvest Science and Technology 6(2):153-160 (In Korean).

Choi, S. J. 2005. Comparison of the Change in Quality and Ethylene Production between Apple and Peach Fruits Treated with 1-Methylcyclopropene (1-MCP). Korean Journal of Food Preservation 12(6):511-515 (In Korean).

Choi, S. R., Y. H. Lee, D. S. Choi and M. S. Kim. 2010. Damage at the peach due to vibrational stress during transportation simulation test. Journal of Biosystems Engineering 35(3):182-188 (In Korean).

Fisk, C. L., A. M. Silver, B. C. Strik and Y. Zhao. 2008. Postharvest quality of hardy kiwifruit (Actinidia arguta 'Ananasnaya') associated with packaging and storage conditions. Postharvest Biology and Technology 47(3): 338-345.

Fuchs, Y., E. Pesis and G. Zauberman. 1980. Change in amylase activity, starch and sugar content in mango fruit pulp. Scientia Horticulture 13(2):155-160.

Grant, S. W., M. T. Turezyn, B. H. Ashby, N. D. Hallee, G. D. Kleinschmidt, F. W. Wheaton and W. L. Dunton. 1986. Potato bruising during transport. Transactions of the ASAE 8(2):241-243.

Hinsch, R. T., D. C. Slaughter, W. L. Craig and J. F. Thompson. 1993. Vibration of fresh fruits and vegetables during refrigerated truck transport. Transactions of the ASAE 36(4):1039-1042.

Hong, Y. P. and E. J. Lee. 2007. Effect of relative humidity under various packaging treatments on quality of grape fruits during cold storage. Korean Journal of 
Horticulture Science \& Technology 25(1):47-53 (In Korean).

Jarimopas, B., S. P. Singh and W. Saengnil. 2005. Measurement and analysis of truck transport vibration levels and damage to packaged tangerines during transit. Packaging Technology and Science 18(4):179-188.

Jung, H. S. and J. U. Choi. 1999. Production of ethylene and carbon dioxide in apples during CA storage. Korean Journal of Food Preservation 6(2):153-160 (In Korean).

Jung, H. M., M. S. Kim and R. Auras. 2010. Effects of packaging materials processed with oak charcoal on the quality of oriental pears during storage and distribution. Journal of Biosystems Engineering 35(5): 316-322 (In Korean).

Kader, A. A., D. Zagory and E. L. Kerbell. 1989. Modified atmosphere packaging of fruits and vegetables. Critical Reviews in Food Science Nutrition 28:1-30.

Kader, A. A. and S. Ben-Yehoshua. 2000. Effects of superatmospheric oxygen levels on postharvest physiology and quality of fresh and vegetables. Postharvest Biology and Technology 20(1):1-13.

Kim, G. S., J. M. Park and M. S. Kim. 2010. Functional shock responses of the pear according to the combination of the packaging cushioning materials. Journal of Biosystems Engineering 35(5):323-329 (In Korean).

Korean Industrial Standard, KS T 1006. 2010. Types of corrugated fiberboard boxes. Seoul, Korea: Korean Standards Association.

Lakshminarayana, S. 1980. Sapodilla and prickly pear. In: S. Nagy and P. E. Shaw (eds.). Tropical and subtropical fruits, pp. 415-441. Westport CT: AVI Pub.

Olorunda, A. O. and M. A. Tung. 1985. Simulated transit studies on tomatoes: effects of compressive loads, container, vibration and maturity on mechanical damages. Journal of Food Technology 20(6):669-678.

Rissi, G. O., S. P. Singh, G. Burgess and J. Singh. 2008. Measurement and analysis of truck transport environment in Brazil. Packaging Technology and Science 21(4): 231-246.

Schulte, P., E. J. Timm, G. K. Brown, D. E. Marshal and C. L. Burton. 1990. Apple damage assessment during intrastate transportation. Transactions of the ASAE 6(6):753-758. Slaughter, D. C., R. T. Hinsch and J. F. Thompson. 1993.
Assessment of vibration injury to Bartlett pears. Transactions of the ASAE 36(14):1043-1047.

Seo, J. Y., E. J. Kim, S. I. Hong, H. W. Park and D. M. Kim. 2005. Respiratory characteristics and quality of Fuji apple treated with mild hot water at critical conditions. Korean Journal of Food Science and Technology 37(3): 372-376 (In Korean).

Soliva-Fortuny, R. C., N. Grigelmo-Miguel, I. Hernando, M. A. Lluch and O. Martin-Belloso. 2002. Effect of minimal processing on the texture and structural properties of fresh-cut pears. Journal of the Science of Food and Agriculture 82(14):1682-1688.

Singh, P. and Y. Singh. 1992. Effects of vibration during transportation on the quality of tomatoes. Agricultural Mechanization in Asia, Africa and Latin America 23(2):70-72.

Singh, S. P., A. P. S. Sandhu, J. Singh and E. Joneson. 2007. Measurement and analysis of truck and rail shipping environment in India. Packaging Technology and Science 20(6):381-392.

Singh, S. P. and M. Xu. 1993. Bruising in apples as a function of truck vibration and packaging. Applied Engineering in Agriculture 9(5):455-460.

Stow, J. R., C. J. Dover and P. M. Genge. 2000. Control of ethylene biosynthesis and softening in 'Cox's orange pippin' apples during low-ethylene, low-oxygen storage. Postharvest Biology and Technology 18(3):215-225.

Turczyn, M. T., S. W. Grant, B. H. Ashby and F. W. Wheaton. 1986. Potato shatter bruising during laboratory handling and transport simulation. Transactions of the ASAE 29(4):1171-1175.

Vergano, P. J., R. F. Testin and Jr. W. C. Newall. 1991. Peach bruising susceptibility to impact, vibration and compression abuse. Transactions of the ASAE 34(5): 2110-2116.

VURSAVUŞ K. and F. ÖZGÜVEN. 2004. Determining the effects of vibration parameters and packaging method on mechanical damage in golden delicious apples. Turkish Journal of Agriculture and Forestry 28(5): 311-320.

Wszelaki, A. L., E. J. Mitcham. 2000. Effects of superatmospheric oxygen on strawberry fruit quality and decay. Postharvest Biology and Technology 20(2):125-133. 